\title{
PENGATUR SUHU DAN KELEMBABAN KUMBUNG JAMUR OTOMATIS
}

\author{
Aji Nugroho', Muhammad Fakhril Kaffah Asyroh $^{2}$, Aji Pangestu ${ }^{3}$, Bekti Wulandari ${ }^{4}$ \\ ${ }^{1234}$ Fakultas Teknik Universitas Negeri Yogyakarta \\ Email: ajinugroho195@gmail.com
}

\begin{abstract}
Temperature and humidity have an important role in the cultivation of oyster mushrooms to obtain optimal growth of oyster mushrooms. The optimal temperature required ranges from $24^{\circ} \mathrm{C}-27^{\circ} \mathrm{C}$ and $80 \%-90 \%$ humidity. Mushroom kumbung must be watered regularly to maintain the temperature and humidity of the surrounding air The purpose of this research is to make a tool that can automatically regulate the temperature and humidity of mushroom kumbung to make it easier for farmers to maintain the stability of temperature and humidity continuously. The optimal temperature needed ranges from $24^{\circ} \mathrm{C}-27^{\circ} \mathrm{C}$ and the optimal humidity is $80 \%-90 \%$. Mushroom kumbung must be watered regularly to maintain the temperature and humidity of the air. The purpose of this research is to make a tool that can automatically regulate the temperature and humidity of mushroom kumbung to make it easier for farmers to maintain the stability of temperature and humidity continuously. This automatic setup system uses the DHT-11 sensor as a measure of the temperature and humidity of the room, and Arduino Uno as the controller. The test is carried out for 7 days with data collection at $06.00 \mathrm{WIB}, 12.00$ WIB, and $16.00 \mathrm{WIB}$. The test results prove that this tool can maintain temperature stability with an average of $25^{\circ} \mathrm{C}$ and room humidity with an average of $60 \%$, with a set point temperature of $27^{\circ} \mathrm{C}$ and set point humidity of $55 \%$.
\end{abstract}

Keywords: temperature, humidity, arduino uno, DHT11, mushroom

\begin{abstract}
ABSTRAK
Suhu dan kelembaban memiliki peranan penting pada budidaya jamur tiram untuk mendapatkan pertumbuhan jamur tiram yang optimal. Suhu optimal yang diperlukan berkisar $24^{\circ} \mathrm{C}-27^{\circ} \mathrm{C}$ dan kelembaban $80 \%-90 \%$. Kumbung jamur harus disiram secara rutin untuk memelihara suhu dan kelembaban udara tersebut. Penelitian ini dilakukan bertujuan untuk membuat alat yang dapat mengatur suhu dan kelembaban kumbung jamur secara otomatis untuk memudahkan petani menjaga kestabilan suhu dan kelembaban ruang secara kontinyu. Sistem pengaturan otomatis ini menggunakan sensor DHT11 sebagai pengukur suhu dan kelembaban udara dan arduino uno sebagai kendali alat. Pengujian dilakukan selama 7 hari dengan pengambilan data pada pagi hari pukul $06.00 \mathrm{WIB}$, siang hari pukul 12.00 WIB dan sore hari pukul 16.00 WIB. Hasil pengujian membuktikan bahwa alat sistem pengaturan suhu dan kelembaban ini dapat menjaga kestabilan suhu dan kelembaban ruang dengan rata-rata $25^{\circ} \mathrm{C}$ dan $60 \%$, dengan set point suhu dan kelembaban $27^{\circ} \mathrm{C}$ dan $55 \%$.
\end{abstract}

Kata kunci : suhu, kelembaban, arduino uno, DHT11, jamur

\section{PENDAHULUAN}

Indonesia merupakan salah satu negara yang terletak di daerah tropik sehingga memiliki keanekaragaman hayati yang tinggi dibandingkan dengan daerah sub tropik (iklim sedang) dan kutub (iklim kutub). Tingginya keanekaragaman hayati ini terlihat dari berbagai macam ekosistem yang ada di Indonesia, seperti: ekosistem pantai, ekosistem hutan bakau, ekosistem padang rumput, ekosistem hutan, hujan tropis, ekosistem air tawar, ekosistem air laut, ekosistem savanna, dan lain-lain. Masing- masing ekosistem ini memiliki keaneragaman hayati tersendiri.

Jamur merupakan salah satu keanekaragaman hayati. Budidaya Jamur belakangan ini banyak sekali orang menekuninya. Di Yogyakarta terdapat lebih dari seratus kelompok pembudidaya jamur tiram. Peminat pembudidaya jamur tiram pun semakin meningkat. Melihat potensi jamur yang dapat tumbuh sepanjang tahun dan kandungan gizi yang terdapat pada jamur tiram merupakan faktor yang memicu 
masyarakat tertarik membudidaya jamur tiram.

Jamur merupakan tanaman yang membutuhkan perawkaatan khusus untuk membudidayakannya, perlu penyiraman yang teratur dan kondisi tempat penanaman yang lembab dan sedikit pengaruh pancaran sinar matahari dapat mengoptimalkan pertumbuhan jamur hingga masa panen. Pada suatu pertanian jamur tiram, suhu, kelembaban sangatlah penting bagi pertumbuhan jamur, maka dibutuhkan sensor yang dapat mendeteksi suhu dan kelembaban pada kumbung jamur tiram agar pertumbuhan jamur tiram lebih optimal. Pada umumnya suhu yang baik bagi jamur tiram adalah antara $24^{\circ} \mathrm{C}$ sampai dengan $27^{\circ} \mathrm{C}$ sedangkan kelembabannya 80\%-90\%.

Menurut penuturan salah seorang petani jamur tiram di Cangkringan cuaca yang tidak menentu mengakibatkan banyak petani jamur tiram yang mengalami kesulitan untuk melakukan pengendalian kumbung jamur agar cocok dengan lingkungan untuk penanaman jamur tiram. Akibatnya keuntungan yang didapatkan petani menurun drastis karena kualitas jamur tiram yang dihasilkan juga menurun.

Perkembangan teknologi otomatisasi telah berlangsung sejak lama, dengan menggunakan teknologi ini pekerjaan manusia akan menjadi lebih efisien dan produk yang dihasilkan juga akan menjadi lebih berkualitas. Efektifitas dan kualitas produk itu dapat diraih melalui teknologi otomatis ini yang menggabungkan beberapa sistem yaitu sistem elektronika, sistem komputer, sistem mekanik, sistem kontrol. Penggabungan sistem ini diharapkan dapat menjadikan proses produksi berjalan secara otomatis sesuai kebutuhan, misalnya dalam mengatur proses penyiraman pada suatu kumbung jamur.

Selama ini, penyiraman tanaman dilakukan secara manual. Penyiraman dilakukan berpedoman pada suhu ruangan yang terukur oleh thermometer. Bila suhu melewati batas standar, pekerja akan mulai melakukan penyiraman. Hal ini cukup menguras tenaga pembudidaya jamur tiram karena harus bolak-balik menyiram jamur demi memperoleh suhu dan kelembaban yang sesuai kebutuhan jamur tiram. Oleh karena itu, para pembudidaya membutuhkan suatu alat yang dapat membantu meringankan kegiatan menyiram jamur tiram. Alat tersebut berupa sistem yang dapat bekerja secara otomatis, dimana penyiraman tanaman dapat dilakukan pada waktu dan suhu yang tepat.

Jamur tiram disebut juga sebagai shimeji atau oyster mushrooms. Jamur tiram putih memiliki ciri khusus yaitu warnanya putih bersih, bentuk daun buahnya bulat pada media antara $3 \mathrm{~cm}-10 \mathrm{~cm}$ dan bertangkai. Jamur ini bisa tumbuh dengan baik pada media serbuk gergaji kayu sengon (Albazia Procera) atau kayu jeungling putih (Paraserianthes Falcataria) dengan tingkat kelembaban tinggi. Jamur tiram putih tidak beracun, selain mengandung nilai gizi yang tinggi, pembudidayaannya relatif mudah. Selain rasanya enak, jamur tiram putih juga mengandung sedikit tepung (pati). Oleh karena itu, jamur tiram putih merupakan makanan yang cocok bagi penderita diabetes dan orang yang ingin mengurangi berat badan, kandungan asam folatnya tinggi sehingga dapat mencegah dan menyembuhkan anemia (kekurangan darah). Jamur ini adalah salah satu jamur yang enak dimakan dan banyak digemari di berbagai negara. Secara umum jamur tiram memberikan banyak manfaat bagi kesehatan tubuh bahkan beberapa di antaranya yang bisa digunakan untuk mengobati berbagai macam penyakit. Jamur tiram merupakan jamur yang tumbuh di kayu sehingga orangorang menyebutnya tanaman perusak kayu. Namun ternyata setelah diteliti jamur tiram memiliki kandungan tersendiri yang dapat membantu penyembuhan beberapa penyakit (Tatang, 2015) 
Jamur tiram (gambar 1) termasuk tumbuhan hasil pertanian organik yang tidak mengandung kolesterol. Setiap 100 gram jamur tiram mengandung protein $19-35 \%$ dengan 9 macam asam amino, lemak 1,7 $2,2 \%$ terdiri dari $72 \%$ asam lemak tak jenuh. Karbohidrat jamur tiram riboflavin dan niasin merupakan vitamin B utama dalam jamur tiram selain vitamin $\mathrm{D}$ dan $\mathrm{C}$ mineralnya terdiri atas $\mathrm{K}, \mathrm{P}, \mathrm{Na}, \mathrm{Ca}, \mathrm{Mg}$, juga $\mathrm{Zn}, \mathrm{Fe}, \mathrm{Mn}, \mathrm{Co}$, dan $\mathrm{Pb}$. Mikroelemen yang bersifat logam sangat rendah sehingga aman dikonsumsi setiap hari (Sumarmi,2006).

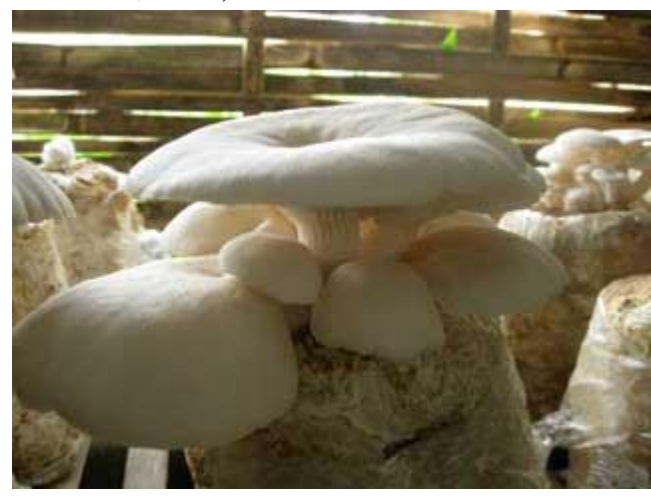

Gambar 1. Jamur Tiram

DHT11 (gambar 2) adalah salah satu sensor yang dapat mengukur dua parameter lingkungan sekaligus, yakni suhu dan kelembaban udara (humidity). Dalam 4 sensor ini terdapat sebuah thermistor tipe NTC (Negative Temperature Coefficient) untuk mengukur suhu, sebuah sensor kelembaban tipe resisitif dan sebuah mikrokontroller 8-bit yang mengolah kedua sensor tersebut dan mengirim hasilnya ke pin output dengan format single-wire bidirectional (kabel tunggal dua arah)(Ajie, 2016).

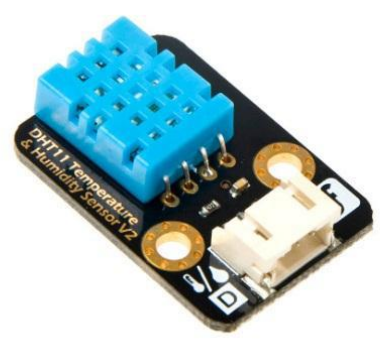

Gambar 2. Dht 11
Arduino Uno (gambar 3) sebenarnya adalah salah satu kit mikrokontroler yang berbasis pada Atmega328. Modul ini sudah dilengkapi dengan berbagai hal yang dibutuhkan untuk mendukung mikrokontroler untuk bekerja. Arduino Uno memilki 14 pin digital input/output, 6 analog input, sebuah resonator keramik $16 \mathrm{MHz}$, port USB, jack power, ICSP header, dan sebuah tombol reset (Febrianto, 2014).

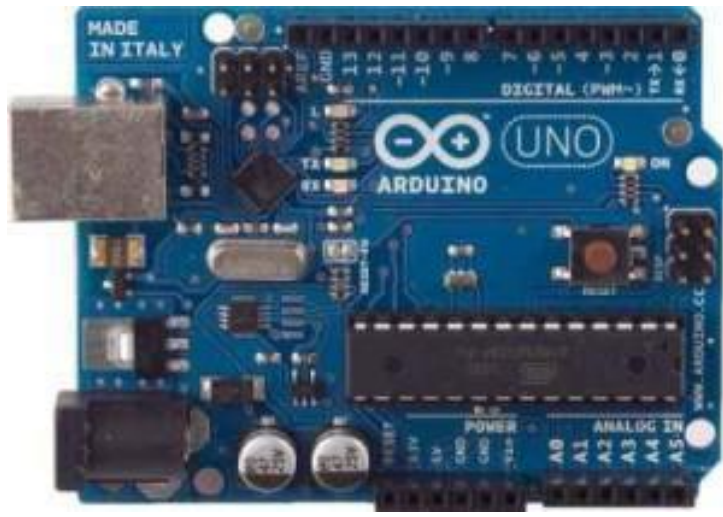

Gambar 3. Arduino Uno

Pompa Air DC merupakan jenis pompa yang menggunakan motor DC dan tegangan searah sebagai sumber tenaganya. Pemberian beda tegangan pada kedua terminal tersebut akan menyebabkan motor berputar pada satu arah, dan bila polaritas dari tegangan tersebut dibalik maka arah putaran motor akan terbalik pula. Polaritas dari tegangan yang diberikan pada dua terminal menentukan arah putaran motor, sedangkan besar dari beda tegangan pada kedua terminal menentukan kecepatan motor.

Sprayer adalah alat yang berfungsi untuk memecah suatu cairan, larutan atau suspensi menjadi butiran cairan (droplets) atau spray (Maya Delistiani, 2014). Nozzle sprayer embun (gambar 4) digunakan untuk membuat embun untuk menurunkan suhu dan menaikkan kelembaban. 


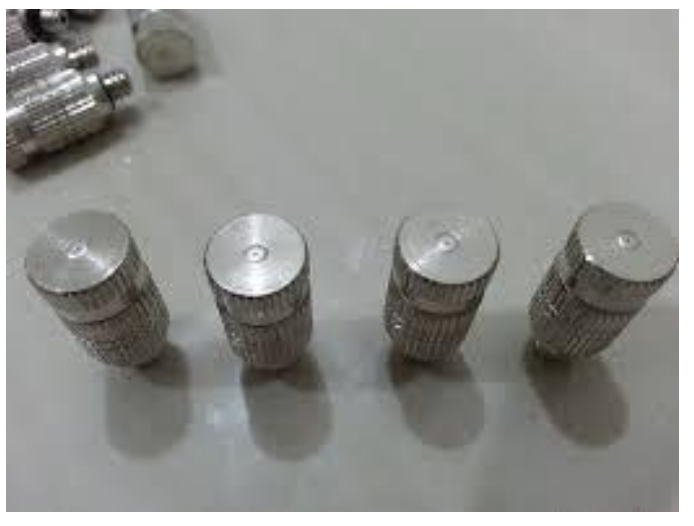

Gambar 4. Nozzle

SIM800L (gambar 5) adalah salah satu modul GSM/GPRS serial yang dapat digunakan bersama Arduino / Raspberry Pi. SIM800L dapat digunakan untuk mengirim SMS, menelpon, dan transfer data melalui GPRS \& fungsi DTMF yang dalam pengoperasiannya sudah mendukung penggunaan frekuensi quad-band (850/900/1800/1900MHz).

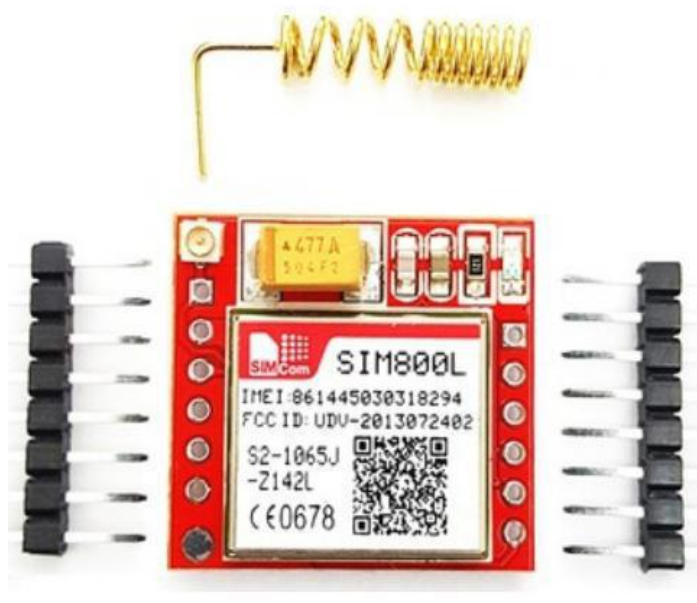

Gambar 5. SIM800L

Komponen realtime clock adalah komponen IC penghitung yang dapat difungsikan sebagai sumber data waktu baik berupa data jam, hari, bulan maupun tahun. Pada penelitian ini komponen yang digunakan sebagai realtime clock adalah DS1307 (gambar 6). DS1307 adalah IC realtime clock yang dilengkapi dengan komponen pendukung lain seperti crystal sebagai sumber clock serta battery external 3,6 Volt sebagai sumber energi cadangan agar fungsi penghitung tidak berhenti.

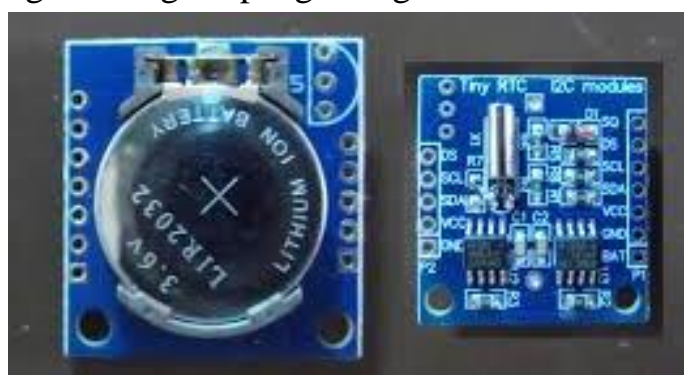

Gambar 6. DS1307

\section{METODE}

Metode yang digunakan untuk mencapai target luaran terdiri menjadi tiga tahapan. Tahap yang pertama adalah mensosialisasikan program yang akan dilaksanakan kepada calon mitra yang ditentukan. Tahap yang kedua yaitu mengadakan kerjasama dengan mitra. Tahap yang ketiga adalah menerapkan alat pengatur suhu dan kelembaban kumbung jamur otomatis. Pelaksanaan penelitian ini dilaksanakan di salah satu petani jamur tiram di umbulharjo, cangkringan, sleman, Provinsi Daerah Istimewa Yogyakarta.

Dalam pelaksanaan pelaksaan terdapat beberapa tahapan. Sebelum melakukan perancangan desain alat, maka langkah awal yang dilakukan adalah menganalisis kebutuhan alat dan bahan. Perlu dilakukan studi literatur yang jelas mengenai komponen apa saja yang dipakai dalam proses pembuatan alat Pengatur Suhu dan Kelembaban Kumbung Jamur Otomatis (PETIS). Selanjutnya perlu dilakukan pendesainan fisik alat yang sesuai dengan kondisi mitra usaha.

Tahapan selanjutnya adalah rancangan desain. Proses pembuatan rancangan dimulai dari perakitan sistem alat. Setelah sistem jadi barulah dilakukan perancangan untuk penempatan alat agar sesuai dengan kondisi lingkungan kebun. Proses pembuatan alat ini harus dilakukan secara hati-hati dan teliti serta melalui tahapan-tahapan pengujian untuk 
meyakinkan alat dapat bekerja maksimum untuk selanjutnya diterapkan. Penerapan penelitian ini dilakukan bersama salah satu petani jamur tiram pada tanggal 26 Juni 2018. Poin-poin masalah yang terjadi selama penerapan alat menjadi landasan untuk melakukan evaluasi. Evaluasi bertujuan untuk mengetahui kelemahan dan kekurangan Pengatur Suhu Dan Kelembaban Kumbung Jamur Otomatis secara keseluruhan sehingga keberlanjutan dari penggunaan teknologi ini dapat menjadi lebih baik. Evaluasi terdiri dari evaluasi produk dan evaluasi alat. Evaluasi produk yaitu perbandingan kualitas hasil saat sebelum dan selama penggunaan Pengatur Suhu Dan Kelembaban Kumbung Jamur Otomatis. Sementara itu, evaluasi alat terdiri dari penggunaan listrik selama pelaksanaan, analisis dampak lingkungan setelah pengaplikasian Pengatur Suhu Dan Kelembaban Kumbung Jamur Otomatis.

\section{HASIL DAN PEMBAHASAN}

Prinsip kerja dari alat pengatur suhu dan kelembaban kumbung jamur otomatis adalah suhu dan kelembaban yang ada pada kumbung akan dibaca oleh sensor selanjutnya data suhu dan kelembaban yang terbaca sensor akan dibandingkan dengan suhu dan kelembaban yang sudah diatur pada arduino uno. Pada saat suhu kumbung jamur melebihi suhu yang telah diatur pada program maka arduino uno akan memberikan sinyal untuk menghidupkan pompa air bertekanan tinggi, air bertekanan tinggi akan disemprotkan kekumbung jamur oleh nozzle sehingga air yang bertekanan tinggi akan diubah menjadi butiran kabut oleh nozzle. Pada saat kelembaban kumbung jamur kurang dari kelembaban yang telah diatur pada program maka arduino uno akan memberikan sinyal untuk menghidupkan pompa air bertekanan tinggi, air bertekanan tinggi akan disemprotkan kekumbung jamur oleh nozzle sehingga air yang bertekanan tinggi akan diubah menjadi butiran kabut oleh nozzle. Data suhu dan kelembaban akan dikirim keserver sehingga kita dapat memonitor suhu dan kelembaban kumbung jamur memalui aplikasi android dan juga kita dapat menghidupkan pompa untuk menyiram jamur dengan aplikasi android.

Mitra sangat puas dengan diterapkannya alat pengatur suhu dan kelembaban otomatis ini karena dengan alat ini penyiraman dapat dilakukan secara otomatis jadi tidak membutuhkan tenaga yang banyak sehingga petani jamur dapat melakukan aktivitas yang lain dan juga monitoring suhu dan kelembaban dapat dilakukan melalui aplikasi android.

Adapun hasil aplikasi dari alat pengatur suhu dan kelembaban kumbung jamur otomatis yaitu sebagai berikut ini :

Tabel 1.

suhu dan kelembaban kumbung jamur setelah dan sebelum penerapan alat

\begin{tabular}{l|ll} 
JAM & SEBELUM & SESUDAH \\
\hline $\mathbf{0 6 . 0 0}$ & $20^{\circ} \mathrm{C} 60 \%$ & $20^{\circ} \mathrm{C} 60 \%$ \\
$\mathbf{1 2 . 0 0}$ & $31^{\circ} \mathrm{C} 45 \%$ & $26^{\circ} \mathrm{C} 63 \%$ \\
$\mathbf{1 6 . 0 0}$ & $26^{\circ} \mathrm{C} 55 \%$ & $25^{\circ} \mathrm{C} 60 \%$
\end{tabular}

Tabel 2.

Hasil kuantitatif produksi jamur sebelum dan sesudah alat diterapkan

\begin{tabular}{lll}
\hline Hari & Sebelum $(\mathbf{K g})$ & Sesudah $(\mathbf{K g})$ \\
\hline $\mathbf{1}$ & 5 & 5,5 \\
\hline $\mathbf{2}$ & 5 & 6 \\
\hline $\mathbf{3}$ & 6 & 7 \\
\hline $\mathbf{4}$ & 5 & 6 \\
$\mathbf{5}$ & 7 & 7,5 \\
\hline $\mathbf{6}$ & 6 & 6,5 \\
\hline $\mathbf{7}$ & 5 & 6 \\
\hline
\end{tabular}

\section{SIMPULAN}

Berdasarkan data yang telah diambil pada program yang telah dilaksanakan, dapat diambil kesimpulan bahwa alat pengatur suhu dan kelembaban kumbung jamur otomatis yang diterapkan pada mitra mampu mengingkatkan kuantitas produksi jamur melalui kemampuan alat untuk 
mengendalikan kestabilan suhu dan kelembaban kumbung jamur.

\section{DAFTAR PUSTAKA}

[1] Tatang Nugraha S.Si. Kiat sukses Budidaya Jamur Tiram. YRAMA WIDYA. 2015.

[2] Sumarmi. Botani dan Tinjauan Gizi Jamur Tiram Putih. 2006. INNOFARM: Jurnal Inovasi Pertanian 4(2) .

[3] Ajie. 2016. Mengukur Suhu dan Kelembaban Udara dengan Sensor DHT11 dan Arduino. Diakses dari: http://saptaji.com/2016/08/10/mengukur- suhu-dan-kelembaban-udara-dengansensor-dht11-dan-arduino/. Pada 20 Oktober 2017.

[4] Febrianto. 2014. Apa itu Arduino Uno?.Diakses dari : https://blogs.itb.ac.id/el2244k01122110 75nurfatonah/2013/04/29/mesin-dc/ Pada 26 Mei 2018.

[5] Delistiani, Maya. 2014. Pengertian, Fungsi, Tujuan, Jenis, serta Bagianbagian Sprayer.Diakses dari : http://maaymeong.blogspot.co.id/2014/1 0/pengertian-fungsi-tujuan-jenisserta.html Pada 21 November 2017. 